\title{
Natural Wool for Removal of Oil Spills from Water Surface
}

\begin{abstract}
ALINA GEORGIANA CIUFU, CRISTIAN EUGEN RADUCANU, OANA CRISTINA PARVULESCU*, DOINITA ROXANA CIOROIU, TANASE DOBRE

University Politehnicaof Bucharest, Chemical and Biochemical Engineering Department, 1-6 Gheorghe Polizu, 011061, Bucharest, Romania

Romanian Merino wool was tested as a natural sorbent for oil spill cleanup. Rebco crude oil placed in distilled water was used as an oily water model. Experiments of batch sorption were performed under various conditions. The effects of process factors, i.e., initial density of packed bed sorbent (0.05-0.99 g/ $\left.\mathrm{cm}^{3}\right)$, initial volume ratio of oil and water $\left(0.25\right.$ and $\left.0.14 \mathrm{~cm}^{3} / \mathrm{cm}^{3}\right)$, and contact surface between adsorbent and oily water, on wool sorption capacity $(6.4-11.8 \mathrm{~g} / \mathrm{g})$ were evaluated. Experimental data were fitted using pseudo-first order rate and pseudo-second order rate models.
\end{abstract}

Keywords: oil spill, kinetic model, sorption capacity, wool fibre

Exploration, production, transport, and storage of oil involve the risk of its spillage that can have harmful effects on the environment and human health [1-6]. Usually, the oil spilled in the water is burned, dispersed or removed by mechanical skimmers or sorbents $[2,3,5,7]$.

Sorption is an effective technique which is widely applied for water remediation and pollutant recovery [1-17]. Synthetic organic materials, e.g., acrylic resins, polyurethane foams, polypropylene and polyester fibres, are the most used sorbents for oil removal and recovery $[2,4,5,11]$. They possess good oleophilic and hydrophobic properties, but are non-biodegradable and generally expensive [1-5,11]. Renewable, biodegradable, and cheap natural sorbents, including wool, coconut coir, cotton, kapok, silk-floss, sisal leaves, palm leaves, sponge gourd, cattail, milkweed, activated carbon, saw dust, rice husk, coconut husk, walnut shell, bagasse, wood chips, human hair, have been extensively tested lately for oil spill removal [1-7,9-17]. Oil sorption using wool and wool-based sorbents can be an attractive method for water remediation due to their low cost, availability, biodegradability, buoyancy, hydrophobicity, and high sorption capacity $[3,6,9,12-17]$.

Sorption capacity and process kinetics mainly depend on oil and sorbenttype, initial volume ratio of oil and water, sorbent dosage, contact time, contact surface between sorbent and oily water, temperature and $\mathrm{pH}$ of oily water.

This paper aimed at testing Romanian Merino wool as a natural sorbent for oil spill cleanup. Rebco crude oil placed in distilled water was used as an oily water model. The effects of process factors in terms of initial density of packed bed sorbent, initial volume ratio of oil and water, and contact surface between adsorbent and oily water were evaluated.

\section{Experimental part \\ Materials}

Romanian Merino wool provided by TRANS-BLAN MOROSAN (Romania) was used as organic sorbent and Rebco crude oil placed in distilled water as oily water. Crude oil was analyzed in the Laboratory of Oil Terminal Constanta (Romania) and its main physical characteristics are given in table 1.

\section{Procedure}

The sorbent was packed into a support and placed in the oily water sample. The system was further shaken in a laboratory shaker (600 rpm) and the sorbent was weighed
Table 1

PHYSICAL PROPERTIES OF REBCO CRUDE OIL AT $22{ }^{\circ} \mathrm{C}$

\begin{tabular}{|l|l|}
\hline Density $\left(\mathrm{g} / \mathrm{cm}^{3}\right)$ & 0.86 \\
\hline Kinematic viscosity $(\mathrm{cSt})$ & 7.84 \\
\hline Dynamic viscosity $(\mathrm{cP})$ & 6.74 \\
\hline Surface tension $($ dyn $/ \mathrm{cm})$ & 30.1 \\
\hline
\end{tabular}

from 5 to 5 min, until the equilibrium was attained. Wool sorption capacity for the crude oil, $q(\mathrm{~g} / \mathrm{g})$, was determined by eq. (1), where $m_{0}(\mathrm{~g})$ is the initial sorbent mass and $m$ (g) the wet sorbent mass (after draining).

$$
q=\frac{m-m_{0}}{m_{0}}
$$

Two experimental runs of batch sorption were performed, according to the support type (fig. 1). A cylindrical support ( $46 \mathrm{~mm}$ diameter, $60 \mathrm{~mm}$ height) with 35 holes ( $2 \mathrm{~mm}$ diameter) at the bottom (fig. 1a) was used in experimental run 1 and a flat support $(62 \mathrm{~mm}$ diameter, $4 \mathrm{~mm}$ height) with 101 holes of $2 \mathrm{~mm}$ diameter (fig. 1b) in the experimental run 2.

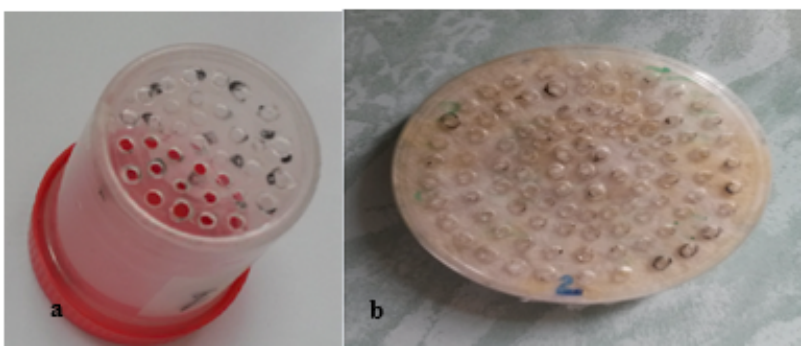

Fig 1. Supports used in the experimental runs 1 (a) and 2 (b).

\section{Experimental run 1}

The sorbent packed into the cylindrical support (fig. 1a) was placed in a flask containing the oily water sample ( $150 \mathrm{~cm}^{3}$ of Rebco crude oil in $600 \mathrm{~cm}^{3}$ distilled water) and the system was shaken until the equilibrium was attained. Two experiments corresponding to values of initial wool mass $\left(m_{0}\right)$ of 5 and $10 \mathrm{~g}$ were performed at room temperature $\left(22^{\circ} \mathrm{C}\right)$.

\section{Experimental run 2}

The sorbent packed into the flat support (fig. 1b) was placed in a crystallizer containing the oily water sample ( $250 \mathrm{~cm}^{3}$ of Rebco crude oil in $1800 \mathrm{~cm}^{3}$ distilled water) 
and the system was shaken until the equilibrium was attained. Three experiments corresponding to values of initial wool mass $(m)$ of 4,8 , and $12 \mathrm{~g}$ were performed at room temperature $\left(22^{\circ} \mathrm{C}\right)$.

\section{Modelling}

Modelling is an effective tool for describing, designing, and optimizing unit operations and chemical processes [18-21]. Pseudo-first and pseudo-second order rate equations have been widely applied to describe batch sorption kinetics [5, 17, 22-30].

Pseudo-first order rate (PFOR) expression of Lagergren [26] is given by eq. (2), where $q$ and $q_{\text {eq }}$ are the sorption capacities at time $\tau$ and at equilibrium, respectively, and $k_{1}$ is the rate constant of PFOR. Eqs. (3)-(5) were obtained from Eq. (2) by separating the variables, integrating, and rearranging the terms. According to eq. (4), kinetic parameters $k_{1}$ and $q_{\text {e }}$ can be obtained from the slope and intercept of the straightline given by a plot of $\ln \left(q_{\mathrm{eq}}-q\right) v s . \tau$.

$$
\begin{aligned}
& \frac{d \underline{g}}{\dot{a} \tau}=k_{1}\left(a_{n_{7}}-g\right) \\
& \int_{0}^{\infty} \frac{1}{q_{s q} g} d q-\int_{0}^{k_{j} d i} \\
& \ln \left(q_{\varphi q}-q\right)=\ln q_{q q}-k_{1} \tau \\
& g=g_{o g}\left(1-e^{-k}\right)
\end{aligned}
$$

Pseudo-second order rate (PSOR) is expressed by eq. (6), where $q$ and $q_{\text {eq }}$ are the sorption capacities at time $\tau$ and at equilibrium, respectively, and $k_{2}$ is the rate constant of PSOR. Eqs. (7)-(10) resulted from eq. (6) by separating the variables, integrating, and rearranging the terms. According to eq. (10), kinetic parameters $q_{\text {e }}$ and $k_{2}$ can be estimated from the slope and intercept of the straight line given by a plot of $\tau / q$ vs. $\tau$.

$$
\begin{aligned}
& \frac{d q}{d \tau}=k_{2}\left(q_{e q}-q\right)^{2} \\
& \int_{0}^{q} \frac{1}{\left(q_{\theta q}-q\right)^{2}} d q=\int_{0}^{\tau} k_{2} d \tau \\
& \frac{1}{q_{e q}-q}=\frac{1}{q_{e q}}+k_{2} \tau \\
& q=\frac{k_{2} \tau q_{e q}{ }^{2}}{1+k_{2} \tau q_{e q}} \\
& \frac{\tau}{q}=\frac{\tau}{q_{e q}}+\frac{1}{k_{2} q_{e q}{ }^{2}}
\end{aligned}
$$

\section{Results and discussions}

\section{Experimental data}

Experimental run 1

The effects of initial density of packed bed wool, $\rho_{b 0}$ $\left(0.05\right.$ and $\left.0.10 \mathrm{~g} / \mathrm{cm}^{3}\right)$, on the dynamics of wool sorption capacity for Rebco crude oil are highlighted in fig. 2. Depicted results reveal that for an initial volume ratio of oil and water $\left(R_{0}\right)$ of $0.25 \mathrm{~cm}^{3} / \mathrm{cm}^{3}$, the equilibrium was attained at $\tau=35 \mathrm{~min}$ and equilibrium sorption capacity $\left(q_{\text {eq }}\right)$ was $7.092 \mathrm{~g} / \mathrm{g}$ for $\rho_{0}=0.05 \mathrm{~g} / \mathrm{cm}^{3}$ and $6.381 \mathrm{~g} / \mathrm{g}$ for $\rho_{b 0}=0.10 \mathrm{~g} / \mathrm{cm}^{3}$. Moreover, the values of initial oil sorption rate, calculated for the first $5 \mathrm{~min}$, were almost equal, i.e., $r_{0} \approx 0.93 \mathrm{~g} / \mathrm{g} / \mathrm{min}$, for both values of $\rho_{b 0^{\prime}}$ whereas those of sorption rate $(r=\mathrm{d} q / \mathrm{d} \tau)$ for $\tau>5$ min were slightly lower for $\rho_{0}=0.10 \mathrm{~g} / \mathrm{cm}^{3}$. Accordingly, for a double value of initial density of packed bed sorbent $\left(\rho_{b 0}=0.10 \mathrm{~g} / \mathrm{cm}^{3}\right)$, values of $q_{\text {eq,exp }}$ were 1.11 times lower, those of $r=\mathrm{d} q / \mathrm{d} \tau(\tau>5 \mathrm{~min})$ werex lower, and $\tau$ and $r$ were similar. In this experimental run, about half of the cylindrical support containing the wool was immersed in the oily water (fig. 3).

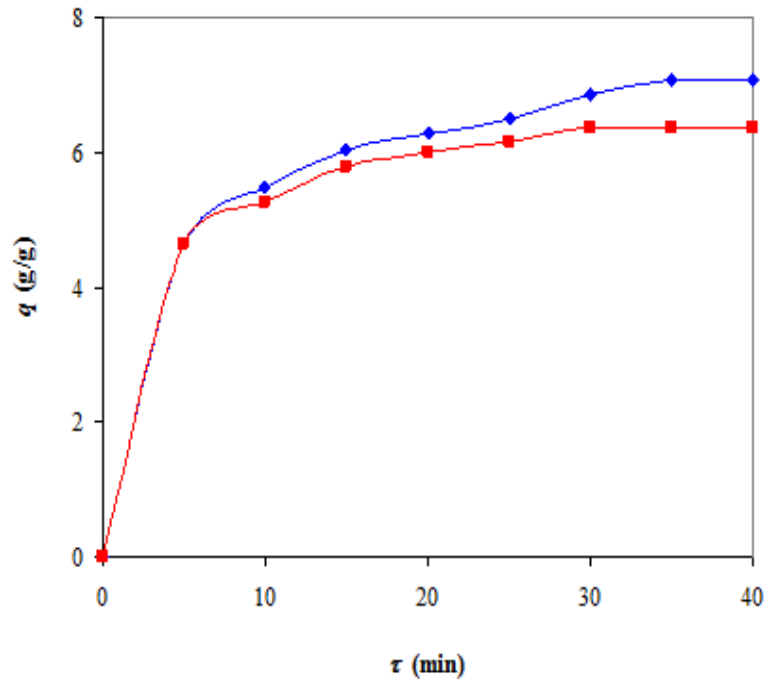

Fig. 2. Experimental dynamics of wool sorption capacity $(q)$ for Rebco crude oil depending on initial density of packed bed wool $\left(\rho_{b 0}\right)$ for experimental run 1: $\rho_{b 0}=0.05 \mathrm{~g} / \mathrm{cm}^{3}, \quad \rho_{b 0}=0.10 \mathrm{~g} / \mathrm{cm}^{3}$ (initial volume ratio of oil and water: $R_{0}=0.25 \mathrm{~cm}^{3} / \mathrm{cm}^{3}$ )

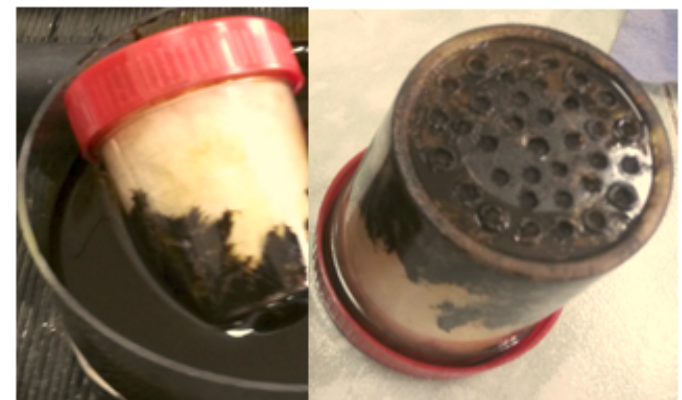

Fig. 3. Crude oil retained by the wool packed into the cylindrical support $\left(\rho_{b 0}=0.05 \mathrm{~g} / \mathrm{cm}^{3}\right)$ after $20 \mathrm{~min}$

Experimental run 2

Data given in fig. 4, highlighting the effects of initial density of thin-bed wool, $\rho_{b 0}\left(0.33,0.66\right.$, and $\left.0.99 \mathrm{~g} / \mathrm{cm}^{3}\right)$, on the dynamics of wool sorption capacity for Rebco crude oil (corresponding to flat support and $R_{0}=0.14 \mathrm{~cm}^{3} / \mathrm{cm}^{3}$ ), emphasize the following issues: (i) $\tau_{\text {eq }}=35 \mathrm{~min}$ and $q_{\text {eq,exp }}=11.76 \mathrm{~g} / \mathrm{g}$ for $\rho_{b 0}=0.33 \mathrm{~g} / \mathrm{cm}^{3}, \tau_{e q}=25 \mathrm{~min}$ and $q_{\text {eq,exp }}=8.094 \mathrm{~g} / \mathrm{g}$ for $\rho_{b 0}=0.66 \mathrm{~g} / \mathrm{cm}^{3}, \tau_{\text {eq }}=25 \mathrm{~min}$ and $q_{\text {eq,exp }}=10.88 \mathrm{~g} / \mathrm{g}$ for $\rho_{b 0}=0.99 \mathrm{~g} / \mathrm{cm}^{3}$; (ii) $r_{0}^{e q}=1.20 \mathrm{~g} / \mathrm{g} / \mathrm{min}$ for $n_{0}=0.33 \mathrm{~g} / \mathrm{cm}^{3}, r_{0}=0.60 \mathrm{~g} / \mathrm{g} / \mathrm{min}$ for $\rho_{b 0}=0.66 \mathrm{~g} / \mathrm{cm}^{3}$, $r_{0}=1.01 \mathrm{~g} / \mathrm{g} / \mathrm{min}$ for $\rho_{b 0}=0.99 \mathrm{~g} / \mathrm{cm}^{3}$. For each experiment in this experimental run, the flat support containing the wool floated on the surface of oily water (fig. 5).

\section{Predicted data}

Characteristic plots of PFOR and PSOR models, i.e., $\ln \left(q_{e}-q\right)$ vs. $\tau$ and $\tau / q$ vs. $\tau$, for experimental runs 1 and 2 are shown in figs. 6 and 7. Kinetic parameters $k_{1}, k_{2}$, and $q_{\text {, }}$ obtained from the slope and intercept of the straight lines in figs. 6 and 7, as well as their corresponding 


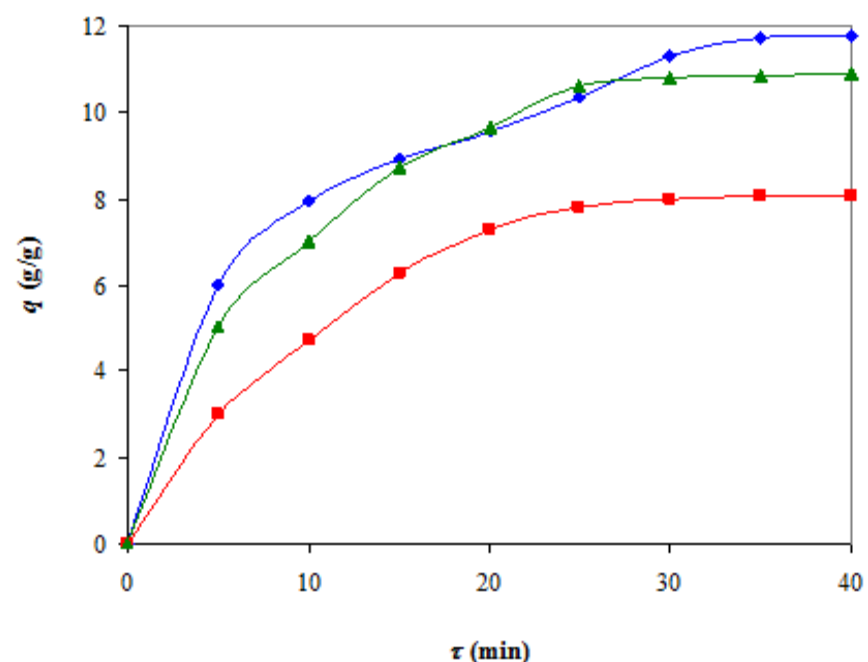

Fig. 4. Experimental dynamics of wool sorption capacity $(q)$ for Rebco crude oil depending on initial density of thin-bed wool $\left(\rho_{b 0}\right)$

for experimental run 2: $\rho_{b 0}=0.33 \mathrm{~g} / \mathrm{cm}^{3},-\rho_{b 0}=0.66 \mathrm{~g} / \mathrm{cm}^{3}$,

$\Delta \rho_{\mathrm{bo}}=0.99 \mathrm{~g} / \mathrm{cm}^{3}$ (initial volume ratio of oil and water: $R_{0}=0.14$ $\left.\mathrm{cm}^{3} / \mathrm{cm}^{3}\right)$.

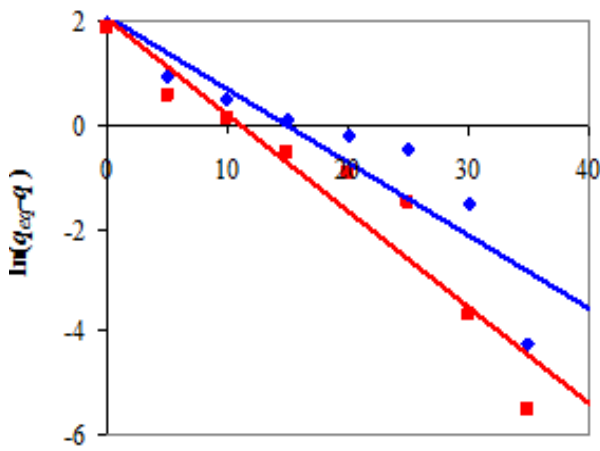

$\tau(\min )$

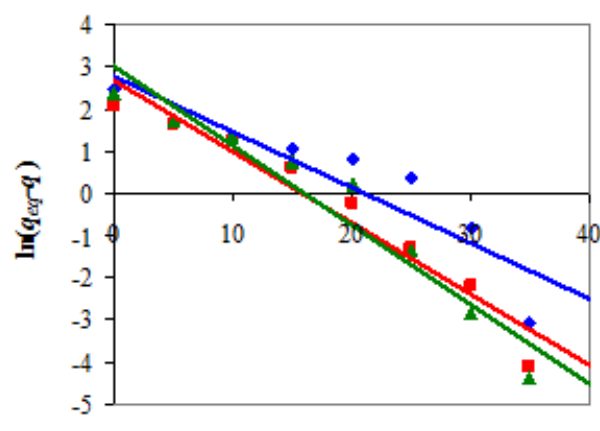

$\tau(\min )$

\begin{tabular}{|c|c|c|c|c|c|c|c|c|c|c|}
\hline \multirow{2}{*}{$\begin{array}{c}R_{0} \\
\left(\mathrm{~cm}^{3} / \mathrm{cm}^{3}\right)\end{array}$} & \multirow{2}{*}{$\begin{array}{c}\rho_{b 0} \\
\left(\mathrm{~g} / \mathrm{cm}^{3}\right)\end{array}$} & \multirow[b]{2}{*}{$\begin{array}{l}q_{\text {eq,exp }} \\
(g / g)\end{array}$} & \multicolumn{4}{|c|}{ PFOR model } & \multicolumn{4}{|c|}{ PSOR model } \\
\hline & & & $\begin{array}{c}q_{e q} \\
(\mathrm{~g} / \mathrm{g})\end{array}$ & $\begin{array}{c}k_{1} \\
\left(\mathrm{~min}^{-1}\right)\end{array}$ & $\begin{array}{l}R S D \\
(\%)\end{array}$ & $R^{2}$ & $\begin{array}{c}q_{e q} \\
(\mathrm{~g} / \mathrm{g})\end{array}$ & $\begin{array}{c}k_{2} \\
\left(\min ^{-1}\right)\end{array}$ & $\begin{array}{l}R S D \\
(\%)\end{array}$ & $R^{2}$ \\
\hline \multirow{2}{*}{0.25} & 0.05 & 7.092 & 7.915 & 0.140 & 192.5 & 0.8425 & 7.805 & 0.030 & 2.17 & 0.9978 \\
\hline & 0.10 & 6.381 & 7.778 & 0.186 & 57.47 & 0.9157 & 6.845 & 0.054 & 1.04 & 0.9995 \\
\hline \multirow{2}{*}{$\begin{array}{c}R_{0} \\
\left(\mathrm{~cm}^{3} / \mathrm{cm}^{3}\right)\end{array}$} & \multirow[b]{2}{*}{$\begin{array}{c}\rho_{b 0} \\
\left(\mathrm{~g} / \mathrm{cm}^{3}\right)\end{array}$} & \multirow[b]{2}{*}{$\begin{array}{c}q_{\mathrm{eq}, \mathrm{exp}} \\
(\mathrm{g} / \mathrm{g})\end{array}$} & \multicolumn{4}{|c|}{ PFOR model } & \multicolumn{4}{|c|}{ PSOR model } \\
\hline & & & $\begin{array}{c}q_{e q} \\
(\mathrm{~g} / \mathrm{g})\end{array}$ & $\begin{array}{c}k_{1} \\
\left(\min ^{-1}\right)\end{array}$ & $\begin{array}{c}\text { RSD } \\
(\%)\end{array}$ & $R^{2}$ & $\begin{array}{c}q_{e q} \\
(\mathrm{~g} / \mathrm{g})\end{array}$ & $\begin{array}{c}k_{2} \\
\left(\min ^{-1}\right)\end{array}$ & $\begin{array}{l}R S D \\
(\%)\end{array}$ & $R^{2}$ \\
\hline \multirow{3}{*}{0.14} & 0.33 & 11.76 & 15.96 & 0.131 & 141.6 & 0.8485 & 14.07 & 0.009 & 3.24 & 0.9935 \\
\hline & 0.66 & 8.094 & 14.44 & 0.169 & 177.2 & 0.9440 & 10.89 & 0.008 & 4.49 & 0.9845 \\
\hline & 0.99 & 10.88 & 20.76 & 0.188 & 237.8 & 0.9338 & 13.45 & 0.009 & 2.95 & 0.9946 \\
\hline
\end{tabular}

determination coefficients $\left(R^{2}\right)$ and relative standard deviations $(R S D)$ are presented in tables 2 and 3 . Tabulated data highlight thatPSOR model, considering chemisorption as rate-determining step [22-24,27,29], provides a better correlation of experimental data $\left(0.9845 \leq R^{2} \leq 0.9995\right.$, $1.04 \% \leq R S D \leq 4.49 \%)$ than PFOR model $\left(0.8425 \leq R^{2} \leq\right.$ $\left.0.9440,57.47 \% \leq R S D d^{\prime \prime} 237.8 \%\right)$. Moreover, the values of

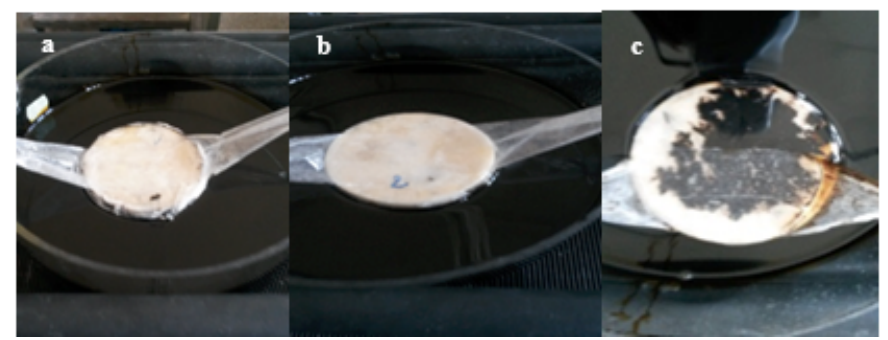

Fig. 5. Thin-bed wool floating on the surface of oily water after 10 $\min :$ (a) $\rho_{b 0}=0.33 \mathrm{~g} / \mathrm{cm}^{3}$, (b) $\rho_{b 0}=0.66 \mathrm{~g} / \mathrm{cm}^{3}$, (c) $\rho_{b 0}=0.99 \mathrm{~g} / \mathrm{cm}^{3}$.
Fig. 6. Characteristic plots of PFOR (a) and PSOR (b) models for experimental run $1: \rho_{b 0}=0.05 \mathrm{~g} / \mathrm{cm}^{3},-\rho_{b 0}=0.10 \mathrm{~g} / \mathrm{cm}^{3}$ $\left(R_{0}=0.25 \mathrm{~cm}^{3} / \mathrm{cm}^{3}\right)$.
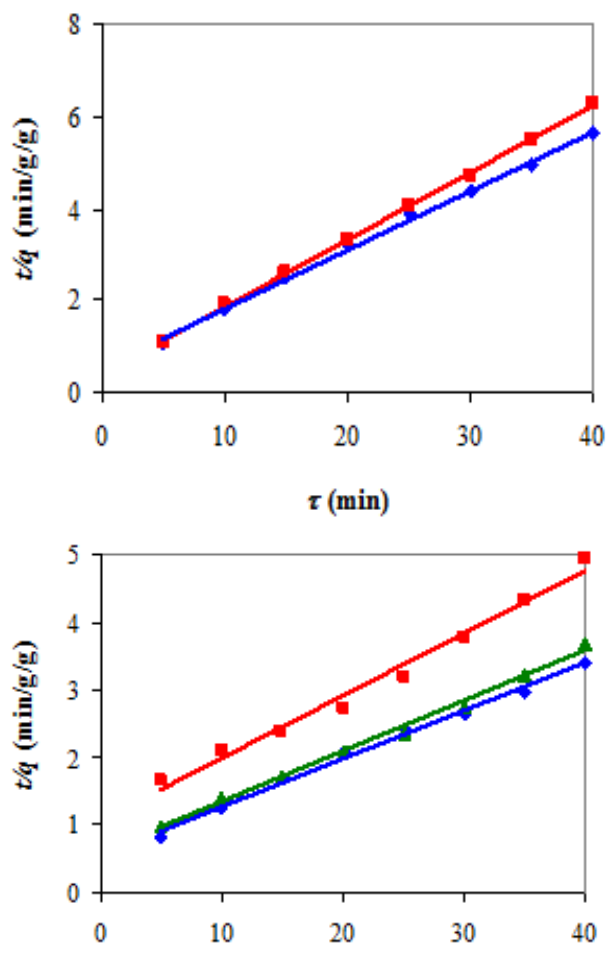

Fig. 7. Characteristic plots of PFOR (a) and PSOR (b) models for experimental run 2: $\rho_{b 0}=0.33 \mathrm{~g} / \mathrm{cm}^{3},-\rho_{b 0}=0.66 \mathrm{~g} /$ $\mathrm{cm}^{3}, \Delta \rho_{b 0}=0.99 \mathrm{~g} / \mathrm{cm}^{3}\left(R_{0}=0.14 \mathrm{~cm}^{3}\right)$ $\left.\mathrm{cm}^{3}\right)$.
Table 2

KINETIC PARAMETERS OF PFOR AND PSOR MODELS FOR EXPERIMENTAL RUN 1

\section{Table 3}

KINETIC PARAMETERS OF PFOR AND PSOR MODELS FOR EXPERIMENTAL RUN 2 


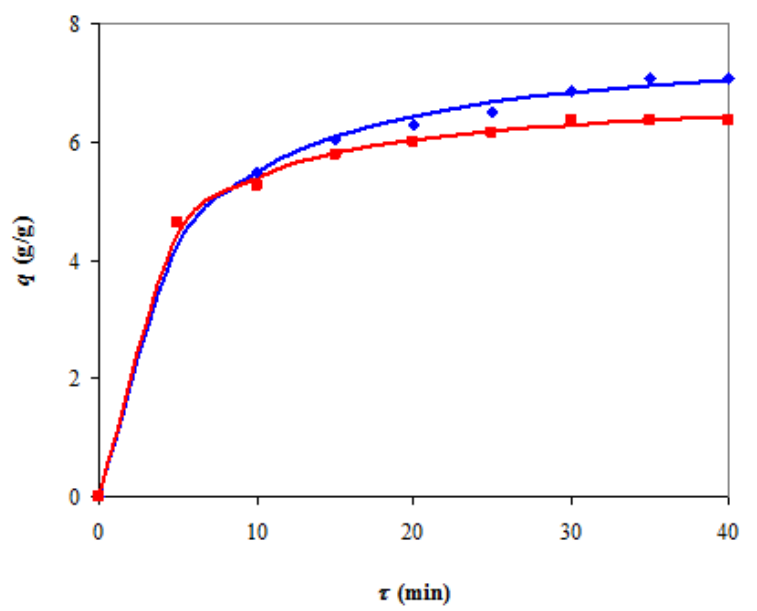

Fig. 8. Experimental and predicted (eq. (5)) dynamics of wool sorption capacity $(q)$ for Rebco crude oil depending on initial density of packed bed wool $\left(\rho_{\text {bo }}\right)$ for experimental run 1 :

- $\rho_{b 0}=0.05 \mathrm{~g} / \mathrm{cm}^{3},-\rho_{b 0}=0.10 \mathrm{~g} / \mathrm{cm}^{3}$ (initial volume ratio of oil and water: $R_{0}=0.25 \mathrm{~cm}^{3} / \mathrm{cm}^{3}$ ).

\section{Conclusions}

The capacity of natural wool to retain crude oil from water was investigated. Experiments of batch sorption were conducted under different conditions. The wool was packed into a cylindrical or a flat support, placed in a mixture of Rebco crude oil and water, and further the system was shaken in a laboratory shaker.

The effects of initial density of packed bed wool $\left(\rho_{b 0}\right)$, initial volume ratio of oil and water $\left(R_{0}\right)$, and support type on the sorption capacity $(q)$ were evaluated. For the cylindrical support, an equilibrium state was attained after $35 \mathrm{~min}$ ( for $R_{0}=0.25 \mathrm{~cm}^{3} / \mathrm{cm}^{3}$ ) and equilibrium values of $q$ were $7.092 \mathrm{~g} / \mathrm{g}$ for $\rho_{b 0}=0.05 \mathrm{~g} / \mathrm{cm}^{3}$ and $6.381 \mathrm{~g} / \mathrm{g}$ for $\rho_{0}=0.10 \mathrm{~g} / \mathrm{cm}^{3}$. For the flat support, equilibrium state was attained after $25-35 \mathrm{~min}$ ( for $R_{0}=0.14 \mathrm{~cm}^{3} / \mathrm{cm}^{3}$ ) and equilibrium values of $q$ were $11.76 \mathrm{~g} / \mathrm{g}$ for $\rho_{b 0}=0.33 \mathrm{~g} / \mathrm{cm}^{3}$, $8.094 \mathrm{~g} / \mathrm{g}$ for $\rho_{b 0}=0.66 \mathrm{~g} / \mathrm{cm}^{3}$, and $10.88 \mathrm{~g} / \mathrm{g}$ for $\rho_{b 0}=0.99$ $\mathrm{g} / \mathrm{cm}^{3}$. Equilibrium values of $q$ determined for both support types are consistent with those reported in the related literature for oil sorption using w ool-based sorbents $[6,9,13$ 16]. Experimental data were correlated using pseudo-first order rate (PFOR) and pseudo-second order rate (PSOR) models. PSOR model, assuming chemisorption as ratedetermining step, provided a better correlation of experimental results.

\section{References}

1. ANNUNCIADO, T.R., SYDENSTRICKER, T.H.D., AMICO, S.C., Mar. Pollut. Bull., 50, 2005, p. 1340.

2. COJ OCARU, C., MACOVEANU, M., CRETESCU, I., Colloids Surf. A Physicochem. Eng. Asp., 384, 2011, p. 675.

3. PERIOLATTO, M., GOZZELINO, G., Chem. Eng. Trans., 43, 2015, p. 2269.

4. TELI, M.D., VALIA, S.P., Carbohydr. Polym., 92, 2013, p. 328.

5. UKOTIJE-IKWUT, P.R., IDOGUN, A.K., IRIAKUMA, C.T., ASEMINASO,

A., OBOMANU, T., International J ournal of Scientific \& Engineering Research, 7, no. 8, 2016, p. 1754.

6. WAHI, R., CHUAH, L.A., CHOONG, T.S.Y., NGAINI, Z., NOUROUZI, M.M., Sep. Purif. Technol., 113, 2013, p. 51.

7. LEE, J.H., KIM, D.H., KIM, Y.D., J. Ind. Eng. Chem., 35, 2016, p. 140. 8. CHIPURICI, P., CALINESCU, I., GAVRILA, A., PREDEANU, G., UPB Sci. Bull. Series B, 72, no. 2, 2010, p. 83.

9. CIUFU, A.G., AL JANABI, A.A.A., PARVULESCU, O.C., DOBRE, T., RADUCANU, C., Rev. Chim. (Bucharest), 69, no. 9, 2018, p. 2575.

10. DONG, T., WANG, F., XU, G., Mar. Pollut. Bull., 91, 2015, p. 230.

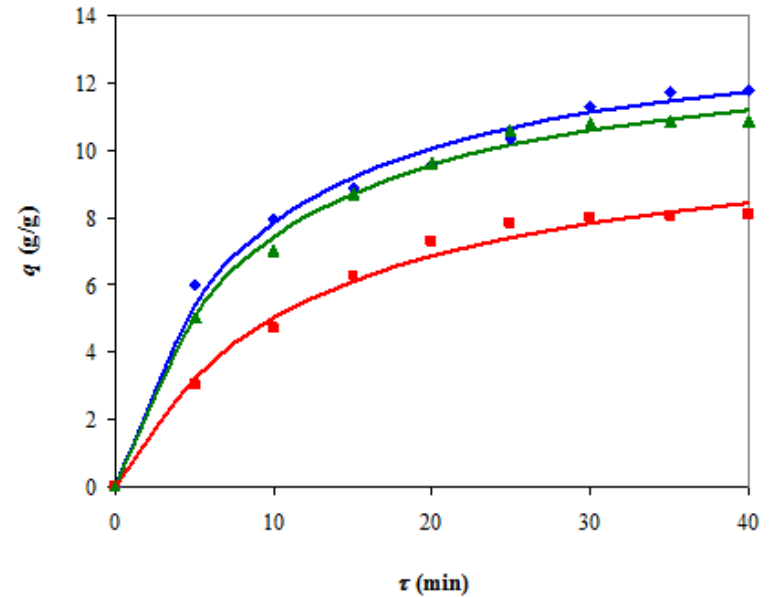

Fig. 9. Experimental and predicted (eq. (9)) dynamics of wool sorption capacity $(q)$ for Rebco crude oil depending on initial density of thin-bed wool $\left(\rho_{b 0}\right)$ for experimental run 2:

- $\rho_{b 0}=0.33 \mathrm{~g} / \mathrm{cm}^{3},-\rho_{b 0}=0.66 \mathrm{~g} / \mathrm{cm}^{3}, \Delta \rho_{b 0}=0.99 \mathrm{~g} / \mathrm{cm}^{3}$ (initial volume ratio of oil and water: $R_{0}=0.14 \mathrm{~cm}^{3} / \mathrm{cm}^{3}$ )

11. DONG, T., XU, G., WANG, F., Ind. Crops Prod., 76, 2015, p. 25.

12. PINTOR, A.M.A., VILAR, V.J.P., BOTELHO, C.M.S., BOAVENTURA, R.A.R., Chem. Eng. J., 297, 2016, p. 229.

13. RADETIC, M., ILIC, V., RADOJ EVIC, D., MILADINOVIC, R., JOCIC, D., JOVANCIC, P., Chemosphere, 70, 2008, p. 525.

14. RADETIC, M.M., JOCIC, D.M., JOVANCIC, P.M., PETROVIC, Z.LJ ., THOMAS, H.F., Environ. Sci. Technol., 37, no. 5, 2003, p. 1008.

15. RAJ AKOVIC, V., ALEKSIC, G., RADETIC, M., RAJAKOVIC, LJ ., J. Hazard. Mater., 143, 2007, p. 494.

16. RAJAKOVIC-OGNJANOVI, V., ALEKSIC, G., RAJAKOVIC, LJ ., J. Hazard. Mater., 154, 2008, p. 558.

17. SIDIK, S.M., JALIL, A.A., TRIWAHYONO, S., ADAM, S.H., SATAR, M.A.H., HAMEED, B.H., Chem. Eng. J., 203, 2012, p.9.

18. DIMA, A.D., MATEESCU, C., PARVULESCU, O.C., LUNGULESCU, E.M., NICULA, N.O., Rev. Chim. (Bucharest), 70, no. 7, 2019, p. 2524. 19. DOBRE, T., PARVULESCU, O.C., STOICA-GUZUN, A., STROESCU, M., JIPA, I., AL JANABI, A.A.A., Int. J. Heat Mass Transfer, 103, 2016, p. 478.

20. GAVRILA, A.I., ASOFIEI, I., CHIPURICI, P., Rev. Chim. (Bucharest), 68, no. 4, 2017, p. 639

21. STOICA, A., DOBRE, T., STROESCU, M., STURZOIU, A., PARVULESCU, O.C., Food Bioprod. Process., 94, 2015, p. 218.

22. BUSUIOC, L.T., SIMONESCU, C.M., NECHIFOR, G., RADOI, E., GIRBEA, I.E., Rev. Chim. (Bucharest), 69, no. 6, 2018, p. 1293.

23. HO, Y.S., MCKAY, G., Process Biochem., 34, 1999, p. 451.

24. KAMAR, F.H., NIAMAT, F.E., FAISAL, A.A.H., MOHAMMED, A.A., NECHIFOR, A.C., NECHIFOR, G., Rev. Chim. (Bucharest), 69, no. 8, 2018, p. 1919.

25. KOWANGA, K.D., GATEBE, E., MAUTI, G.O., MAUTI, E.M., The Journal of Phytopharmacology, 5, no. 2, 2016, p. 71.

26. LAGERGREN, S., Kungliga Svenska Vetenskapsakademiens Handlingar, 24, no. 4, 1898, p. 1.

27. NEAGU, M., POPOVICI, D.R., DUSESCU, C.M, CALIN, C., Rev. Chim. (Bucharest), 68, no. 1, 2017, p. 139.

28. PASCU (NEAGU), M., PASCU, D.E., TRAISTARU, G.A., BUNACIU, A.A., ORBECl, C., NECHIFOR, A.C., Rev. Chim. (Bucharest), 64, no. 8, 2013, p. 1.

29. PATESCU, R.E., SIMONESCU, C.M., ONOSE, C., BUSUIOC, L.T., PASARICA, D.E., DELEANU, C., Rev. Chim. (Bucharest), 68, no. 1, 2017, p. 1293.

30. RADU, E., OPRESCU, E.E., ENASCUTA, C.E., CALIN, C., STOICA, R., VASILE SCAETEANU, G., VASILIEVICI, G., CAPRA, L., IVAN, G., ION, A.C., Rev. Chim. (Bucharest), 69, no. 1, 2018, p. 191.

$\overline{\text { Manuscript received: } 20.12 .2018}$ 